\title{
Sugarbeet Growth, Yield Components, Quality and Nitrogen Use Efficiency as Influenced by Sources and Rates of Nitrogen Fertilizer
}

\author{
Hossam M. EL-Sharnoby
}

\begin{abstract}
Two split trials with four replications were conducted at the Bangar El- Sukar region, Burg El- Arab, Alex. Governorate, Egypt during 2018/19 and 2019/20 seasons to study the effect of two nitrogen sources fertilizers (ammonium sulphate $20.6 \%$ and urea $46 \%$ ) with three rates $(80,100$ and $120 \mathrm{Kg} \mathrm{N} /$ fed.) on growth, yield components and quality characters and nitrogen use efficiency of sugarbeet grow on a clay loam soil. Results showed that significant differences were reported between sources of nitrogen fertilizer in the most plant growth characters, yield components, quality parameters and impurity parameters as well as nitrogen use efficiency (NUE) in the two seasons. Beet plants fertilized with ammonium sulphate as compared with urea significantly exceeded root and top fresh weight, root length, root diameter, leaf area index and total dry matter accumulation per plant as growth parameters, roots, top, gross sugar and white sugar as yield components, percentage of gross sugar, white sugar, quality index as quality parameters and NUE for yields of roots, gross sugar, white sugar and loss sugar in both seasons, and chlorophyll "a" in first season only. On contrary, also, ammonium sulphate significantly decreased concentrations of $\mathrm{K}, \mathrm{Na}, \alpha$ - amino- $\mathrm{N}$ as impurities and loss sugar \% as compared with urea in both seasons. Application of different rates of nitrogen fertilizer in the two seasons, significantly affected all tested traits, except loss sugar yield and quality index in the first season only. Application of $120 \mathrm{Kg} \mathrm{N} / \mathrm{fed}$. rate recorded the highest values of all tested plant characters, photosynthetic contents, yield components, quality parameters and NUE for gross sugar and white sugar yields. . In addition, the same nitrogen rate produced the lowest values for all impurity parameters measured $(\mathrm{K}, \mathrm{Na}, \alpha-$ amino- $\mathrm{N}$ and AC), loss sugar percent, NUE for roots and loss sugar yields in the both seasons. The interaction between sources and rates of nitrogen fertilizer were significant effect on root length and fresh weight/ plant in first season only, root diameter, chlorophyll "b", gross sugar yield/ fed. , all quality parameters and NUE for loss sugar yield in the second season only. However, in the two seasons, roots, top and white sugar yields/ fed. and all impurities as well as NUE for roots, gross sugar and white sugar yields were significantly affected by the interaction between sources and rates of nitrogen fertilizer. In general, application ammonium sulphate fertilizer at the rate of $120 \mathrm{Kg} \mathrm{N} / \mathrm{fed}$. was recommended because it recorded the highest root characterse, chlorophyll "b", most yield components and quality traits as well as NUE for gross sugar and white
\end{abstract}

sugar yields, and the lowest loss sugar yield, loss sugar \%, NUE for roots yield and all impurities traits.

Key words: Sugarbeet, Nitrogen sources, rates, quality, yield, Growth, Use efficiency.

\section{INTRODUCTION}

In Egypt, nowadays, sugarbeet (Beta vulgaris L.), is the first source of sugar production. The production of sugar from sugarbeet reached $58.9 \%$ according to Sugar Crops Council, 2020.

Nitrogen is one of the most abundant elements on earth. It accounts for $78 \%$ of the earth's atmosphere in the form of $\mathrm{N}_{2}$. Plants require nitrogen for their metabolic processes as well as growth. It is key component of amino acids, the building blocks of proteins, as well as chlorophyll. Primary cells are found to have about $5 \%$ of nitrogen. It plays a vital role in various metabolic activities. It helps in harvesting solar energy through chlorophyll, in energy transformation through phosphorylated components, in transfer of genetic information through nucleic acids. Moreover, it is essential in cellular and protein metabolism and acts as biological catalyst (Naresh, 2020).

Nitrogen is a major nutrient element for sugarbeet and it's needed to large amount for high yield of sugarbeet and it considered the most factor affecting the growth and productivity of sugarbeet. Source of nitrogen application is important management tools in this respect because maximum nitrogen efficiency is obtained when nitrogen is applied in the form which is available for uptake by plant needed.

It is very important to use adequate rates and sources of nitrogen, for it successful implementation. Such proposal not only increases yield but also reduce production cost and environmental pollution. The main of this study was to evaluate the effect of two sources and three rates of nitrogen fertilizer on growth, yield components and quality of sugarbeet. In addition, use efficiency of the tested previous factors on roots and sugar yields in clay loam soil.

\section{MATERIALS AND METHODS}

Two split plot field trials with four replications were conducted at the Bangar El- Sukar region, Burg El- Arab, Alex. Governorate, Egypt during 2018/ 19 and 
$2019 / 2020$ seasons to study the effect of two nitrogen fertilizer sources (ammonium sulphate $20.6 \%$ and urea $46 \%$ ) with three rates $(80,100$ and $120 \mathrm{Kg} \mathrm{N} / \mathrm{fed}$.) on plant characters, photosynthetic pigment contents, yield components, quality parameters and concentrations of impurities in juice roots of sugarbeet cultivar, Heba (polygerm) in clay loam soil. Physical properties of the experimental soil were analysis using the procedure described by Black et al. (1981). Soil chemical analysis was determined according to the methods of Jackson (1973). The physical and chemical analysis of experimental soil (at $30 \mathrm{~cm}$ depth) were tabulated in Table (1). Sources and rates of nitrogen fertilizer were randomly allocated in main and sup-plot, respectively. The experimental unit was $18 \mathrm{~m}^{2}$ including 5 rides of 6 $\mathrm{m}$ in length and $60 \mathrm{~cm}$ in width, with $20 \mathrm{~cm}$ between hills. The soil was ploughed triple, settled, ridged and divided into plots. The recommended dose of phosphorus fertilizer was applied at a rate of $100 \mathrm{Kg}$ calcium super phosphate/ fed. $\left(15.5 \% \mathrm{P}_{2} \mathrm{O}_{5}\right)$ during soil preparation. Two- three of sugarbeet seeds cv. Heba were sown in hill on one side of ridge on September 10 and 15 in the first and second seasons, respectively. Plots were flooded irrigated immediately after sowing. Potassium in the form of potassium sulphate $\left(48 \% \mathrm{~K}_{2} \mathrm{O}\right)$ was added at rate $100 \mathrm{Kg} \mathrm{K} \mathrm{K}_{2} \mathrm{O} /$ fed. in two equal portions after thinning (4- 6 true- leaf stage) and 30 days later, respectively. nitrogen fertilizer was applied in three equal portions, the first was applied after thinning and the $2^{\text {nd }}$ and $3^{\text {rd }}$ portions were added at two weeks intervals after the first one, respectively. Other agricultural practices were kept the same as normally practiced in growing sugarbeet fields.

\section{The recorded data:}

After 150 days from sowing, a representative sample of ten plants was randomly taken from the guarded ridges of each sub- plot to determine the following:

- Leaf area index (LAI), which was determined as described by Watson (1958) using the following equation:

$$
\text { LAI }=\frac{\text { Leaf area per plant }(\text { cm } 2)}{\text { plant ground area }(c m 2)}
$$

Where: plant leaf area was determined using the "disk method" in 50 leaf disks of $1.0 \mathrm{~cm}$ diameter.

- Photosynthetic pigments (mg/g) were determined in the fresh leaves as mentioned by

Grodzinsky and Grodzinsky (1973). Chlorophyll $\mathrm{a}$ and $\mathrm{b}$ concentrations in $\mathrm{mg}$ per gm leaves were calculated as follows:

$\mathrm{Ca}=(12.7 \times \mathrm{Ob} . *$ at $663-2.69 \times \mathrm{Ob}$. At 645$) \times 0.2 * *$ $\mathrm{Cb}=\left(22.9 \times \mathrm{Ob}^{*}\right.$ at $645-4.68 \times$ Ob. At 663$) \times 0.2^{* *}$

Ob. $=$ absorption

$0.2=1 /$ [weight of leaves sample $(250 \mathrm{mg}) /$ volume of aceton $(50 \mathrm{~m})]$

\section{- Total dry matter accumulation:}

Each sample was separated into blades, petioles and roots. The roots of each sample were cut to small pieces. All plant fractions were air- dried then oven dried to constant weight for 48 hours at $90^{\circ} \mathrm{C}$. The sum of dried plant fractions was used to calculate the total dry matter accumulation per plant.

Table 1. Physical and chemical analysis of experimental soil during 2018/ 19 and 2019/ 20 seasons

\begin{tabular}{|c|c|c|c|c|c|c|}
\hline \multicolumn{7}{|c|}{ Physical analysis } \\
\hline Seasons & $\begin{array}{c}\text { Sand } \\
\%\end{array}$ & $\begin{array}{c}\text { Silt } \\
\%\end{array}$ & $\begin{array}{c}\text { Clay } \\
\%\end{array}$ & Soil texture & $\begin{array}{c}\text { Bulk density } \\
\text { g/ } \mathrm{Cm}^{3}\end{array}$ & $\begin{array}{c}\text { Saturation } \\
\%\end{array}$ \\
\hline $2018 / 19$ & 32.70 & 22.30 & 36.51 & Clay loam & 1.31 & 30.74 \\
\hline $2019 / 20$ & 31.71 & 25.40 & 35.71 & Clay loam & 1.26 & 28.11 \\
\hline
\end{tabular}

\section{Chemical analysis}

\begin{tabular}{|c|c|c|c|c|c|c|c|c|c|c|c|c|c|c|c|c|}
\hline \multirow[t]{2}{*}{ seasons } & \multicolumn{4}{|c|}{$\begin{array}{l}\text { Soluble anions } \\
(\mathrm{Meq} / \mathrm{L})\end{array}$} & \multicolumn{4}{|c|}{$\begin{array}{c}\text { Soluble cations } \\
(\mathrm{Meq} / \mathrm{L})\end{array}$} & \multicolumn{4}{|c|}{$\begin{array}{l}\text { Available nutrients } \\
\text { (mg/ Kg soil) }\end{array}$} & \multirow[t]{2}{*}{$\mathrm{CaCO}_{3}$} & \multirow{2}{*}{$\begin{array}{c}\text { Organic } \\
\text { Matter } \\
\%\end{array}$} & \multirow{2}{*}{$\begin{array}{c}\text { Ec } \\
\text { (ds/ } \\
\text { m) }\end{array}$} & \multirow[t]{2}{*}{ pH } \\
\hline & $\mathrm{CO}_{3}^{--}$ & $\mathrm{HCO}_{3}^{--}$ & $\mathrm{Cl}^{-}$ & $\mathrm{SO}_{4}^{--}$ & $\mathrm{Ca}^{++}$ & $\mathrm{K}^{+}$ & $\mathrm{Mg}^{++}$ & $\mathrm{Na}^{+}$ & $\mathrm{K}$ & $\mathrm{N}$ & $\mathrm{P}$ & $\mathrm{B}$ & & & & \\
\hline $2018 / 19$ & 0.00 & 3.11 & 5.30 & 4.25 & 2.52 & 0.51 & 3.62 & 4.40 & 70.15 & 21.96 & 6.18 & 0.13 & 4.91 & 1.18 & 1.32 & 8.3 \\
\hline $2019 / 20$ & 0.00 & 3.55 & 5.57 & 4.43 & 2.96 & 0.92 & 3.20 & 6.10 & 67.29 & 20.86 & 5.18 & 0.11 & 4.50 & 1.24 & 1.15 & 8.1 \\
\hline
\end{tabular}


At harvest, plants in the three inner ridge of each plot were collected and cleaned, therefore roots and top were separated and weighted in kilogram and converted to estimate roots and top yields (tons/ fed.). A sample of ten plants was randomly taken from each plot to determine root length, root diameter $(\mathrm{cm})$ and fresh weights of root and top (gm)/ plant. Also, a random sample of $10 \mathrm{Kg}$ roots was taken from each plot and sent to Beet Laboratory Nil Sugar Factory to determine, Alpha amino nitrogen $(\alpha-$ amino- $N)$, sodium $(\mathrm{Na})$ and potassium (K) concentrations (expressed as milliequivalents/ $100 \mathrm{~g}$ beet) were estimated according to the procedure of Sugar Company by Euto Analyzer described by Cooke and Scott (1993). Sucrose\% (expressed as pol\%) was estimated in fresh samples of sugarbeet roots by using Saccharometer according to the method described by A.O.A.C. (1995). Sugar loss\% was calculated using the following formula:

* Loss sugar\% $=[0.29+0.343(\mathrm{~K}+\mathrm{Na})+0.094(\alpha-$ amino- N)].

* Sugar recovery (white sugar\%) was calculated using the following equation:

* White sugar \% = Sucrose $\%$ - loss sugar $\%$.

* White sugar yield (tons/ fed.) $=$ White sugar $\% \times$ roots yield (tons/ fed.).

* Quality index was calculated as (White sugar $\times 100$ )/ Sucrose\%.

* Gross sugar yield (tons/ fed.) = roots yield (tons/ fed.) $\times$ Sucrose $\%$.

* Loss sugar yield (tons/ fed.) $=$ roots yield (tons/ fed.) $\times$ Loss sugar $\%$.

* Alkalinity coefficient $(\mathrm{AC})=\frac{\mathrm{K} \%+\mathrm{Na} \%}{a-\mathbb{N}}$

Nitrogen utilization efficiency (NUE) for roots and sugar yields $(\mathrm{Kg} / \mathrm{Kg} \mathrm{N})$ was calculated as:

* NUE for roots yield $=\underline{\text { Roots yield at } \mathrm{N}_{\mathrm{x}} \text { rate }, \mathrm{Kg}}$ roots/ K N

\section{$\mathrm{N}_{\mathrm{x}}$ rate}

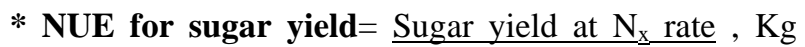
sugar/ K N

$\mathrm{N}_{\mathrm{x}}$ rate

Where: $\mathrm{N}_{\mathrm{x}}=$ roots or sugar yields at the nitrogen rate of 80 or 100 or $120 \mathrm{Kg} \mathrm{N} / \mathrm{fed}$.

The analysis of variance of split plot experiments was carried out using COSTAT computer software for both seasons were done- Least Significant Difference (L.S.D) method was used to test the differences between treatment means at $5 \%$ level of probability.

\section{RESULTS AND DISCUSSION}

\section{I-Plant characters:}

Results of the effect of sources and rates of nitrogen fertilizer on plant characters, root and top fresh weight/ plant, root length, root diameter and total dry matter accumulation of sugarbeet are shown in Table (2). The results indicated that all the previously mentioned traits were significantly affected by nitrogen sources in the two seasons. In general, applying ammonium sulphate fertilizer significantly increased root and top fresh weight/ plant, root length and root diameter as well as total dry matter accumulation/ plant, compared with urea fertilizer in the two seasons. In this concern, Khedr and Nemeat- Alla (2006); El- Sheref (2007); AbouShady et al. (2008) and Allam (2009), they found that fertilized sugarbeet by all nitrogen sources (ammonium nitrate, ammonium sulphate and urea) gave the highest values of root length and root fresh weight. Concerning between ammonium sulphate and urea, El- Sonbaty et al. (2012) reported that no significant difference between ammonium sulphate and urea on root length and root weight. Also, no significant difference between ammonium sulphate and urea in root diameter, root length and root fresh weight (Hozayn et al. (2014). On the other hand, in the most plant characters of sugarbeet, application of ammonium sulphate was superior affected in compared with urea (Attia and Khalifa, 2015).

The results in the same Table, also, revealed that the previously mentioned plant characters were significantly affected by nitrogen rates in both seasons. These characters were increased significantly by increasing nitrogen rate from 80 up to $120 \mathrm{Kg} \mathrm{N} / \mathrm{fed}$. in the two seasons. Application of $120 \mathrm{Kg} \mathrm{N} / \mathrm{fed}$. rate gives the highest root fresh weight $(1125.71 \& 1034.72$ gm), top fresh weight (431.15 \& $444.08 \mathrm{gm})$, root length $(33.36 \& 30.65 \mathrm{~cm})$, root diameter $(12.59 \&$ $12.41 \mathrm{~cm})$ and total dry matter $(121.68 \& 111.15 \mathrm{gm})$ in the first and the second seasons, respectively as shown in Table (2). A positive effect of increasing nitrogen rate on root size, fresh weight of root and top/ plant may be due to role of nitrogen in development and survival of new tillers through synthesis of nucleic acids and other organelles (Allam, 2003). In this respect, increasing rate up to $120 \mathrm{Kg} \mathrm{N} /$ fed. significantly increased length and perimeter of root and fresh weight of root and leaves/ plant (Maareg et al., 2005 a \& b; Abou El- Ghaite and Mohamoud, 2005; Osman, 2011; Sarhan, 2012; Abdou et al., 2014 and El- Geddawy and Makhlouf, 2015).

The interaction between nitrogen and application rates was significant for root fresh weight/ plant (in both seasons), for root length (in the first season) and root 
diameter (in the second season). Applying ammonium sulphate fertilizer at the rate of $120 \mathrm{Kg} \mathrm{N} /$ fed. gave the maximum values of root fresh weight/ plant, root length and root diameter, while, the minimum ones were obtained by applying urea at the rate of $80 \mathrm{Kg} \mathrm{N} / \mathrm{fed}$. This results may be ammonium sulphate is a source of $\mathrm{NH}^{+4}$ which is more readily taken up by plants than urea from soil or the inferiority of urea may be due to a considerable loss of $\mathrm{N}$ - urea out root zone either by leach or volatilization (Ismail and Abo El- Ghait, 2005 and Hozayn et al., 2014).

\section{II- Leaf area index and photosynthetic pigment contents:}

Leaf area (LAI) is the main character that has a direct relation with the processes of light interception and competition in plant communities. Chlorophylls "a" and " $b$ " are the main pigments needed for light energy absorption, and both pigment synthesis requires $\mathrm{Mg}$. A normal response to the $\mathrm{Mg}$ deficiency is a reduction in chlorophyll concentrations (Mengutary et al., 2013; Faust, 2016 and Trankner et al., 2016).

The effect of sources and rates of nitrogen fertilizer on LAI per plant and photosynthetic pigment contents, chlorophylls "a" and "b" as well as total chlorophylls "a $+b$ " in leaves of sugarbeet plant $\mathrm{mg} / \mathrm{gm}$ fresh weight is shown in Table (3).

Results in this Table, nitrogen sources (ammonium sulphate and urea) significantly affected LAI in the two seasons. Application nitrogen fertilizer in form ammonium sulphate significantly exceeded LAI as compared with urea fertilizer in both seasons. On the other hand, chlorophylls "a", "b" and total chlorophylls were insignificantly affected by nitrogen sources in both seasons.

Form the same Table, nitrogen rates exerted significant effect on LAI and photosynthetic contents, chlorophyll "a", "b" and total chlorophylls in beet leaves in the two seasons. Nitrogen fertilization significantly increased LAI, chlorophylls "a", "b" and total chlorophylls and any increase in nitrogen rate applied was always followed by a significant increase in values of all previously mentioned traits in the both seasons. The highest values of LAI (5.19 \& 5.00), chlorophyll "a' (36.39 \& 35.71), chlorophyll "b' (19.40 \& 19.49) and total chlorophylls $(55.79 \& 55.20 \mathrm{mg} / \mathrm{gm}$ beet leaves) were obtained with added nitrogen at the rate of $120 \mathrm{Kg}$ $\mathrm{N} /$ fed. in both seasons, respectively. Also, increasing nitrogen rate up to $120 \mathrm{Kg} \mathrm{N} /$ fed. significantly increased LAI (El- Kady, 2015). On the other hand, low- $\mathrm{N}$ stress significantly decreased chlorophyll contents in sugarbeet leaves (Wu et al., 2012). However, Fei et al. (2020) found that chlorophyll parameters varied significantly at different nitrogen levels.

The interaction between sources, and rates of nitrogen fertilizer on LAI and photosynthetic contents was not significant in both seasons except, chlorophyll "b" was significant in the second season, only. The greatest (19.67) and lowest (17.43 mg/ g leaves) values of chlorophyll "b" were obtained by applying ammonium sulphate at the rates of 120 and $80 \mathrm{Kg} \mathrm{N} /$ fed. (Table, 3).

Table 2. Effect of the two sources and three rates of nitrogen fertilizer on plant characters of sugarbeet during 2018/ 19 and 2019/20 seasons

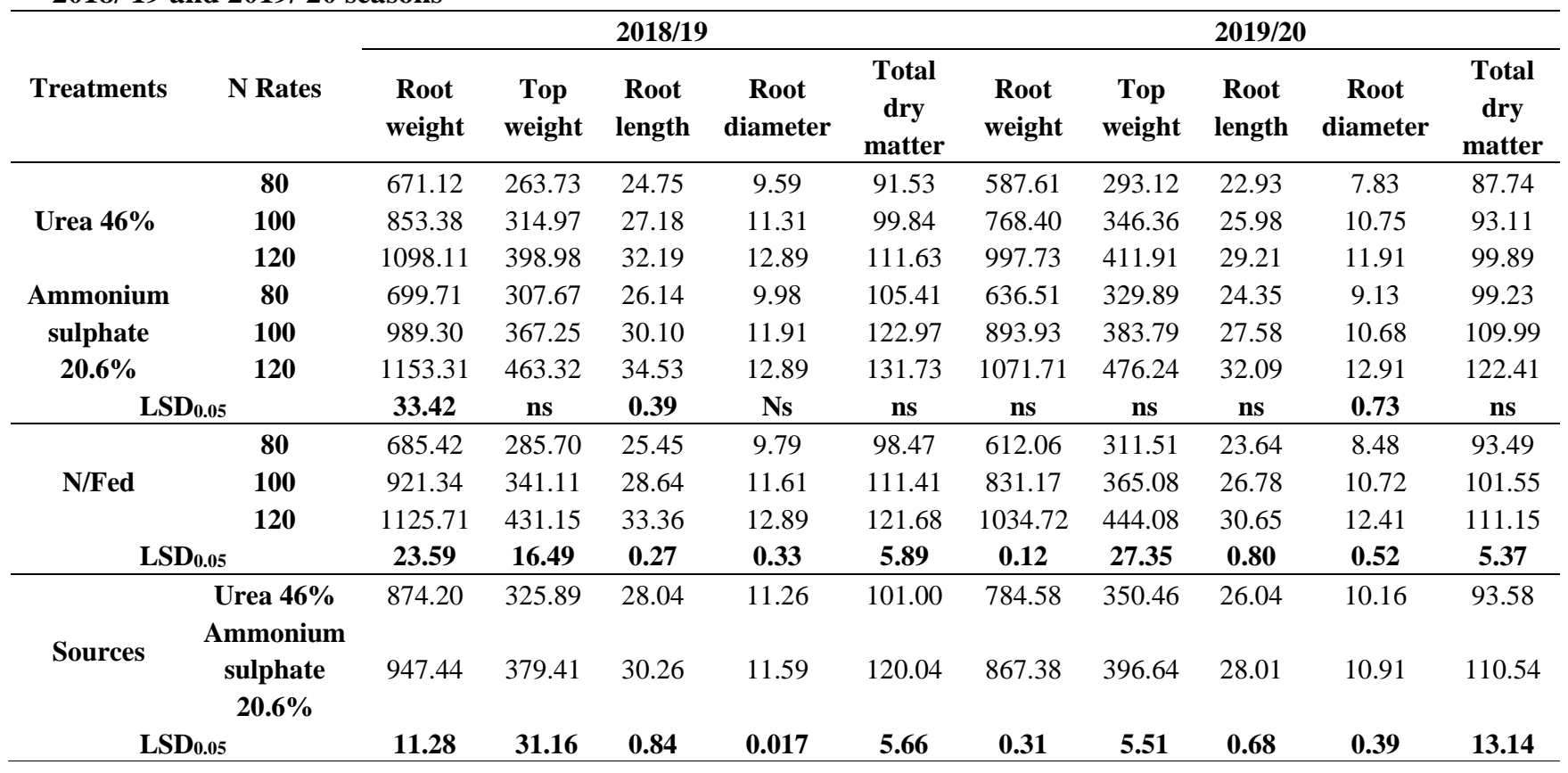


Table 3. Effect of the two sources and three rates of nitrogen fertilizer on leaf area index and photosynthetic pigment contents in leaves of sugarbeet plants during 2018/19 and 2019/20 seasons

\begin{tabular}{|c|c|c|c|c|c|c|c|c|c|}
\hline \multirow{2}{*}{ Treatments } & \multirow{2}{*}{ N Rates } & \multicolumn{4}{|c|}{$2018 / 19$} & \multicolumn{4}{|c|}{$2019 / 20$} \\
\hline & & LAI & Chl. a & Chl. b & Chl. T & LAI & Chl. a & Chl. b & Chl. T \\
\hline \multirow{3}{*}{ Urea $46 \%$} & 80 & 3.90 & 33.31 & 18.03 & 51.34 & 3.57 & 33.82 & 17.89 & 51.71 \\
\hline & 100 & 4.17 & 34.54 & 18.77 & 53.31 & 4.00 & 34.65 & 18.68 & 53.33 \\
\hline & 120 & 5.04 & 35.95 & 19.29 & 55.24 & 4.81 & 36.10 & 19.31 & 55.41 \\
\hline Ammonium & 80 & 4.13 & 34.31 & 18.61 & 52.92 & 4.09 & 33.13 & 17.43 & 50.56 \\
\hline sulphate & 100 & 4.61 & 35.71 & 19.01 & 54.72 & 4.47 & 34.45 & 18.37 & 52.82 \\
\hline $20.6 \%$ & 120 & 5.35 & 36.83 & 19.51 & 56.34 & 5.18 & 35.31 & 19.67 & 54.98 \\
\hline \multicolumn{2}{|c|}{$\mathbf{L S D}_{0.05}$} & ns & ns & ns & ns & Ns & ns & 0.34 & ns \\
\hline \multirow{4}{*}{ N/Fed } & 80 & 4.01 & 33.81 & 18.32 & 52.13 & 3.83 & 33.48 & 17.66 & 51.14 \\
\hline & 100 & 4.39 & 35.13 & 18.89 & 54.02 & 4.24 & 34.55 & 18.53 & 53.08 \\
\hline & 120 & 5.19 & 36.39 & 19.40 & 55.79 & 5.00 & 35.71 & 19.49 & 55.20 \\
\hline & LSD $_{0.05}$ & 0.12 & 5.89 & 0.35 & 1.01 & 0.30 & 5.37 & 0.24 & 0.81 \\
\hline \multirow{3}{*}{ Sources } & Urea $46 \%$ & 4.37 & 34.60 & 18.70 & 53.30 & 4.13 & 34.86 & 18.63 & 53.48 \\
\hline & $\begin{array}{c}\text { Ammonium } \\
\text { sulphate } \\
20.6 \%\end{array}$ & 4.69 & 35.62 & 19.04 & 54.66 & 4.58 & 34.30 & 18.49 & 52.79 \\
\hline & LSD $_{0.05}$ & 0.31 & 5.66 & ns & ns & 0.20 & ns & ns & ns \\
\hline
\end{tabular}

\section{II1-Yield components:}

Data in Table, 4 showed that nitrogen fertilizer sources exerted significant effect on roots, top, gross sugar and white sugar yields/ fed. in the two seasons. However, nitrogen sources did not attributed any significant difference in loss sugar yield in both seasons. Beet plants were fertilized with ammonium sulphate fertilizer significantly exceeded than those fertilized with urea fertilizer. This excess represented $(14.91 \&$ 20.2), (31.75 \& 46.43), (21.74 \& 22.14) and (26.06 \& $23.40 \%$ ) on roots, top gross sugar and white sugar yields in the first and the second seasons, respectively. In this respect, El- Sonbaty et al., (2012) reported that urea fertilizer significantly increased roots and sugar yields as compared with ammonium sulphate. However, Hozayn et al. (2014) found that no significant difference between ammonium sulphate and urea in yield components, roots, top, gross sugar, white sugar and loss sugar tons/ fed. On the other hand, Attia and Khalifa (2015) reported that the application nitrogen fertilizer in the form of ammonium sulphate significantly increased most yield components in compared with urea fertilizer.

Also, nitrogenous fertilization exhibited significant differences for all yield components in both seasons. Nitrogenous fertilization significantly increased the roots yield, top yield, gross sugar yield and white sugar yield (tons/ fed.) and any increase in nitrogen applied was followed by a respective increment in these yields. However, loss sugar yield was gradually increased by increasing nitrogen rate from 80 up to 100 and $120 \mathrm{Kg}$
N/ fed., without significant difference between 100 and $120 \mathrm{Kg} \mathrm{N} /$ fed. rates applications (Table, 4).

Application of $120 \mathrm{Kg} \mathrm{N} /$ fed. rate gave the highest values $\{(29.51 \& 25.29),(9.51 \& 8.72),(5.73 \& 5.47)$, (4.91 \& 4.86) and $(0.87 \& 0.61$ tons/ fed.) $\}$ for roots, top, gross sugar, and white sugar and loss sugar yields in the first and the second seasons, respectively. In the contrary, the rate of $80 \mathrm{Kg} /$ fed. gained the lowest ones. This is due to the increase in the accumulation of total dry matter in the root as a result of higher LAI, root size, as well as weight accompanying nitrogen application in three equal portions.

The interaction between nitrogen sources and their rates significantly affected sugarbeet yield components, except, loss sugar yield in both seasons. The highest values of roots, (31.50 \& 30.60), top, (10.31 \& 10.19), gross sugar, $(6.38 \& 6.06)$ and white sugar, $(5.60 \& 5.42$ tons/ fed.) were obtained by adding ammonium sulphate at $120 \mathrm{Kg} \mathrm{N} /$ fed. rate in the first and second seasons, respectively, On the other hand, the lowest ones were reported at $80 \mathrm{Kg} \mathrm{N} /$ fed. rate of urea in the two seasons.

Many investigators study the effect of nitrogen rates of nitrogen fertilizer on sugarbeet yield components. They concluded that the maximum roots, gross sugar, top and biological yields achieved when nitrogen application at $80 \mathrm{Kg} \mathrm{N} /$ fed. (Agami, 2005), and adding $90 \mathrm{Kg} \mathrm{N} /$ fed. gave only the highest gross sugar yields (Osman et al., 2010), roots, top and gross sugar yields (Gharib and El- Hanawy, 2011) and roots only (Soliman et al., 2013). However, nitrogen at the rates of $100-110 \mathrm{Kg} \mathrm{N} / \mathrm{fed}$. recorded the maximum top, 
roots and gross sugar tons/ fed. (Abd- El- Kader, 2011 and Gomea et al., 2017), yields of roots and gross sugar (Moustafa et al., 2011 and Shaban et al., 2014), and only roots yield (Kandil et al., 2016). Increasing nitrogen rate up to $120 \mathrm{Kg} \mathrm{N} /$ fed. significantly increased top, roots and gross sugar yields (Maareg et al., 2005 a\& b; El- Sarag, 2008 and El- Geddawy and Makhlof, 2015), roots and sugar yields (Ibrahim et al., 2005 and Sarhan, 2012), yields of roots and top, but gross sugar yield decreased (Osman, 2011 and ElSayed, 2013), yields of roots, top, gross sugar, white sugar and loss sugar (Abdou et al., 2014), and roots and white sugar yields only (El- Kady, 2015). On the other hand, increasing nitrogen rate up to $140 \mathrm{Kg} \mathrm{N} / \mathrm{fed}$. significantly increased roots and gross sugar, tons/ fed. (Abdou, 2013) in addition to roots, top, biological, gross sugar, white sugar and loss sugar yields (Mekdad, 2015) and Maareg et al. (2020).

Table 4. Effect of the two sources and three rates of nitrogen fertilizer on sugarbeet yield components (tons/fed.) during 2018/19 and 2019/20 seasons

\begin{tabular}{|c|c|c|c|c|c|c|c|c|c|c|c|}
\hline \multirow[b]{2}{*}{ Treatments } & \multirow[b]{2}{*}{ N Rates } & \multicolumn{5}{|c|}{ 2018/19 } & \multicolumn{5}{|c|}{$2019 / 20$} \\
\hline & & $\begin{array}{l}\text { Roots } \\
\text { Yield }\end{array}$ & $\begin{array}{l}\text { Top } \\
\text { Yield }\end{array}$ & $\begin{array}{l}\text { Gross } \\
\text { Sugar } \\
\text { Yield }\end{array}$ & $\begin{array}{l}\text { White } \\
\text { sugar } \\
\text { Yield }\end{array}$ & $\begin{array}{c}\text { Loss } \\
\text { Sugar } \\
\text { yield }\end{array}$ & $\begin{array}{l}\text { Roots } \\
\text { Yield }\end{array}$ & $\begin{array}{l}\text { Top } \\
\text { Yield }\end{array}$ & $\begin{array}{l}\text { Gross } \\
\text { Sugar }\end{array}$ & $\begin{array}{l}\text { White } \\
\text { sugar } \\
\text { Yield }\end{array}$ & $\begin{array}{c}\text { Loss } \\
\text { Sugar } \\
\text { yield }\end{array}$ \\
\hline \multirow{3}{*}{ Urea $46 \%$} & 80 & 19.80 & 5.62 & 3.44 & 2.76 & 0.68 & 17.16 & 4.73 & 3.05 & 2.58 & 0.47 \\
\hline & 100 & 25.15 & 6.92 & 4.46 & 3.61 & 0.85 & 21.19 & 5.65 & 3.87 & 3.35 & 0.51 \\
\hline & 120 & 27.51 & 8.71 & 5.08 & 4.21 & 0.87 & 25.97 & 7.25 & 4.88 & 4.29 & 0.58 \\
\hline \multirow{3}{*}{$\begin{array}{c}\text { Ammonium } \\
\text { sulphate } \\
20.6 \%\end{array}$} & 80 & 23.45 & 8.50 & 4.13 & 3.31 & 0.78 & 19.83 & 6.91 & 3.44 & 2.92 & 0.52 \\
\hline & 100 & 28.31 & 9.17 & 5.30 & 4.44 & 0.82 & 26.87 & 8.74 & 4.91 & 4.27 & 0.64 \\
\hline & 120 & 31.50 & 10.31 & 6.38 & 5.60 & 0.86 & 30.60 & 10.19 & 6.06 & 5.42 & 0.64 \\
\hline \multicolumn{2}{|c|}{ LSD $_{0.05}$} & 0.23 & 0.19 & ns & 0.14 & ns & 0.98 & 0.22 & 0.33 & 0.29 & ns \\
\hline \multirow{3}{*}{ N/Fed } & 80 & 21.63 & 7.06 & 3.79 & 3.03 & 0.73 & 18.50 & 5.82 & 3.25 & 2.75 & 0.49 \\
\hline & 100 & 26.73 & 8.05 & 4.88 & 4.03 & 0.84 & 24.03 & 7.20 & 4.39 & 3.81 & 0.58 \\
\hline & 120 & 29.51 & 9.51 & 5.73 & 4.91 & 0.87 & 28.29 & 8.72 & 5.47 & 4.86 & 0.61 \\
\hline \multicolumn{2}{|c|}{$\mathbf{L S D}_{0.05}$} & 0.16 & 0.13 & 0.34 & 0.10 & ns & 0.69 & 0.15 & 0.23 & 0.21 & 0.04 \\
\hline \multirow[b]{2}{*}{ Sources } & $\begin{array}{c}\text { Urea 46\% } \\
\text { Ammonium }\end{array}$ & 24.15 & 7.08 & 4.33 & 3.53 & 0.80 & 21.44 & 5.88 & 3.93 & 3.41 & 0.52 \\
\hline & $\begin{array}{c}\text { sulphate } \\
20.6 \%\end{array}$ & 27.75 & 9.33 & 5.27 & 4.45 & 0.82 & 25.77 & 8.61 & 4.80 & 4.21 & 0.60 \\
\hline \multicolumn{2}{|c|}{$\mathbf{L S D}_{0.05}$} & 0.12 & 0.41 & 0.42 & 0.12 & ns & 1.46 & 0.45 & 0.36 & 0.27 & ns \\
\hline
\end{tabular}

Table 5. Effect of two sources and three rates of nitrogen fertilizer on sugarbeet quality during 2018/ 19 and 2019/20 seasons

\begin{tabular}{|c|c|c|c|c|c|c|c|c|c|}
\hline \multirow[b]{2}{*}{ Treatments } & \multirow[b]{2}{*}{ N Rates } & \multicolumn{4}{|c|}{ 2018/19 } & \multicolumn{4}{|c|}{$2019 / 20$} \\
\hline & & $\begin{array}{c}\text { Gross } \\
\text { Sugar\% }\end{array}$ & $\begin{array}{c}\text { White } \\
\text { sugar\% }\end{array}$ & $\begin{array}{c}\text { Loss } \\
\text { sugar } \\
\%\end{array}$ & $\begin{array}{l}\text { Quality } \\
\text { index\% }\end{array}$ & $\begin{array}{c}\text { Gross } \\
\text { Sugar\% }\end{array}$ & $\begin{array}{c}\text { White } \\
\text { sugar\% }\end{array}$ & $\begin{array}{c}\text { Loss } \\
\text { sugar } \\
\%\end{array}$ & $\begin{array}{l}\text { Quality } \\
\text { index\% }\end{array}$ \\
\hline \multirow{3}{*}{ Urea $46 \%$} & 80 & 17.38 & 13.92 & 3.46 & 86.24 & 17.78 & 14.34 & 3.44 & 85.94 \\
\hline & 100 & 17.73 & 14.34 & 3.39 & 82.47 & 18.23 & 15.16 & 3.07 & 84.26 \\
\hline & 120 & 18.45 & 15.30 & 3.37 & 82.80 & 18.76 & 15.86 & 2.90 & 85.41 \\
\hline \multirow{3}{*}{$\begin{array}{c}\text { Ammonium } \\
\text { sulphate } \\
\mathbf{2 0 . 6 \%}\end{array}$} & 80 & 17.59 & 14.11 & 3.48 & 84.24 & 17.33 & 14.04 & 3.29 & 84.97 \\
\hline & 100 & 18.72 & 15.69 & 3.03 & 85.02 & 18.28 & 15.29 & 2.99 & 85.18 \\
\hline & 120 & 20.23 & 17.78 & 2.45 & 87.48 & 19.76 & 17.07 & 2.69 & 87.62 \\
\hline \multicolumn{2}{|c|}{ LSD $_{0.05}$} & ns & ns & Ns & ns & 0.44 & 0.53 & 0.53 & 1.19 \\
\hline \multirow{3}{*}{ N/Fed } & 80 & 17.49 & 14.01 & 3.47 & 85.24 & 17.56 & 14.19 & 3.37 & 85.46 \\
\hline & 100 & 18.23 & 15.01 & 3.21 & 83.75 & 18.26 & 15.23 & 3.03 & 84.72 \\
\hline & 120 & 19.34 & 16.54 & 2.91 & 85.14 & 19.26 & 16.46 & 2.80 & 86.52 \\
\hline \multicolumn{2}{|c|}{ LSD $_{0.05}$} & 0.25 & 0.24 & 0.29 & ns & 0.31 & 0.37 & 0.37 & 0.84 \\
\hline \multirow{3}{*}{ Sources } & $\begin{array}{c}\text { Urea } 46 \% \\
\text { Ammonium }\end{array}$ & 17.85 & 14.52 & 3.41 & 83.84 & 18.26 & 15.12 & 3.14 & 85.20 \\
\hline & $\begin{array}{l}\text { sulphate } \\
20.6 \%\end{array}$ & 18.85 & 15.86 & 2.99 & 85.58 & 18.46 & 15.46 & 2.99 & 85.92 \\
\hline & $\mathbf{L S D}_{0.05}$ & 0.53 & 1.18 & 1.18 & 0.31 & 0.01 & 0.09 & 0.09 & 0.42 \\
\hline
\end{tabular}




\section{IV- Quality parameters:}

Data in Table, (5) showed that nitrogen sources had a significant effect on all tested quality traits in both seasons. In generally, beet received ammonium sulphate produced the highest gross sugar, white sugar and quality index $\%$, while, those received urea produced the lowest ones in the two seasons. On contrary, loss sugar\% was high with urea, and low with ammonium sulphate in both seasons.

Nitrogen rates exerted significant effect on quality parameters, gross sugar, white sugar and loss sugar in the two seasons, and on quality index\% in the second season only. Increasing nitrogen rate from $80 \mathrm{Kg} \mathrm{N} /$ fed. upto $120 \mathrm{Kg} \mathrm{N} / \mathrm{fed}$. increasing significantly increased gross sugar and white sugar\%, and any increase in nitrogen rate was always followed by a significant increase in these traits. However, increasing nitrogen rate from 80 to 100 and $120 \mathrm{Kg} \mathrm{N} /$ fed. gradually decreasing loss sugar\% without signefecant difference between 80 and $100 \mathrm{Kg} \mathrm{N} / \mathrm{fed}$. rates of application in both seasons. Application of $120 \mathrm{Kg} \mathrm{N} / \mathrm{fed}$. rate recorded the highest values of gross sugar and white sugar\% (in both seasons) and quality index (in the second season only), and the lowest values of loss sugar\% in both seasons.

The interaction between sources and rates of nitrogen fertilizer was significant on gross sugar, white sugar and quality index\% in the second season only. In this season, results indicated that ammonium sulphate at the application rate of $120 \mathrm{Kg} \mathrm{N} / \mathrm{fed}$. recoded the highest gross sugar\% (19.76\%), white sugar\% (17.07) and quality index $\%$ (87.62), while, application ammonium sulphate at the rate of $80 \mathrm{Kg} \mathrm{N} / \mathrm{fed}$. recoded the lowest gross sugar\% (17.33) and white sugar\% (14.74). Conversely, the lowest quality index\% (84.26) was recorded with urea at rate of $100 \mathrm{Kg} \mathrm{N} /$ fed. as shown in Table (5).

\section{V- Impurity parameters:}

The soluble non- sugar, potassium $(\mathrm{K})$, sodium $(\mathrm{Na})$, alpha- amino $\mathrm{N}(\alpha$-amino $\mathrm{N})$ in the beet roots are regarded as impurities because they interfere with sugar extraction. Results of these impurities and alkalinity coefficient $\{(\mathrm{K}+\mathrm{Na}) / \alpha-\mathrm{N}\}$ as affected by sources and rates of nitrogen fertilizer were presented in Table (6).

From the same Table, alpha- amino N ( $\alpha$-amino $N)$ concentration was significantly influence by nitrogen sources in the both seasons. However, $\mathrm{K}$ and $\mathrm{Na}$ concentrations were significantly affected by nitrogen sources in the first and the second seasons, respectively. On the other hand, alkalinity coefficient (AC) was not significant influenced by nitrogen sources in both seasons. In general, urea fertilizer significantly increased $\mathrm{K}, \mathrm{Na}$ and $\alpha$ - amino $\mathrm{N}$ as impurities as compared with ammonium sulphate fertilizer.

The results in this study revealed that nitrogen sources had a significant effect on all tested quality and impurity traits. Application of ammonium sulphate significantly increased quality parameters and decreased impurity concentrations in roots of sugarbeet. In this concern, Ismail and Abo El- Hgait (2005) reported that ammonium sulphate application recorded the lowest sucrose, white sugar and purity $\%$ as quality percentages, and the highest $\mathrm{K}$ and $\alpha$ - amino- $\mathrm{N}$ concentrations in compared with urea, however, El- Sombaty et al. (2012) found that application ammonium sulphate significantly increased in most quality percentages and quantity of sugarbeet as compared with urea. On the other hand, no significant difference between ammonium sulphate and urea fertilizers in the quality and imprity parameters, except, loss sugar\% and $\mathrm{K}$ - concentration (Hozayn et al., 2014). While, source nitrogen fertilizer as ammonium sulphate exhibited a significant increase in all quality percentages as compared with urea fertilizer (Attia and khalifa 2015).

Nitrogen fertilization exerted significant effect on concentrations of $\mathrm{K}, \mathrm{Na}, \alpha$-amino $\mathrm{N}$ and $\mathrm{AC}$ in beet roots in the two seasons. Increasing nitrogen from 80 to $120 \mathrm{Kg} \mathrm{N} /$ fed. significantly decreased $\mathrm{K}, \mathrm{Na}$ and $\alpha$ amino $\mathrm{N}$ concentrations, and in the two seasons, any rise in nitrogen rate was often accompanied by a substantial decrease in these listed trails. With regard to AC, application of 80 and 120 nitrogen rates significantly decreased its value as compared to $100 \mathrm{Kg}$ $\mathrm{N} /$ fed. rate in the two seasons.

The interaction between nitrogen sources and application rates was significant for $\mathrm{K}, \mathrm{Na}, \alpha$ - amino- $\mathrm{N}$ and $\mathrm{AC}$ in both seasons. The lowest values of the mentioned impurities ( $\mathrm{K}, \mathrm{Na}, \alpha$ - amino- $\mathrm{N}$ ) were obtained with application of ammonium sulphate at the rate of $120 \mathrm{Kg} \mathrm{N} / \mathrm{fed}$. in both seasons. However, the lowest value of $\mathrm{AC}$ was record with ammonium sulphate at 120 and $80 \mathrm{Kg} \mathrm{N} /$ fed. rates in the first and second seasons, respectively.

In this respect, several workers revealed that the effect of nitrogen fertilizer at $120 \mathrm{Kg} \mathrm{N} /$ fed. on $\mathrm{Na}, \mathrm{K}$, $\alpha-\mathrm{N}$ and alkalinity coefficient (Ac) were no significant (Nemeat Alla, 2009). However, increasing $\mathrm{N}$ rate up to $120 \mathrm{Kg} \mathrm{N} /$ fed. significantly increased juice impurities i.e. $\mathrm{Na}, \mathrm{K}$ and $\alpha-\mathrm{N}$ contents, whereas, gross sugar, white sugar content and purity\% were decreased (ElSayed, 2013). Also, fertilizing sugarbeet plants with 120 $\mathrm{Kg} \mathrm{N} /$ fed. produced the highest T.S.S\%, however, the highest gross sugar and purity\% were resulted from control treatment (Sarhan, 2012 and Abdelaal \& Tawfik, 2015). On the other hand, increasing $\mathrm{N}$ rate up 
to $120 \mathrm{Kg} \mathrm{N} /$ fed. significantly increased loss sugar\%, on contrary, it significantly decreased gross sugar and white sugar contents (Abdou et al., 2014). Also, increasing $\mathrm{N}$ rate up to $120 \mathrm{Kg} \mathrm{N} /$ fed. significantly increased impurities, $\mathrm{K}, \mathrm{Na}$ and $\alpha-\mathrm{N}$, whereas, insignificant on white sugar and purity\% (El- Kady, 2015).

VI- Nitrogen utilization efficiency (NUE) for sugarbeet yields $(\mathrm{Kg} / \mathrm{Kg} \mathrm{N})$.

Data of NUE for roots and sugar yield components as affected by sources and rates of nitrogen fertilizer are presented in Table (7). Nitrogen sources had a significant effect on NUE for roots, gross sugar and white sugar yields in the two seasons, and only on loss sugar yield in the first season only. Beet plants received ammonium sulphate fertilizer significantly exceeded those received urea fertilizer in the NUE values for previously mentioned yield components in both seasons. These excess were about $(15.17 \& 20.03),(21.37 \&$ $21.43),(25.38 \& 22.53)$ and $(3.95 \& 14.37 \%)$ in NUE for roots, gross sugar, white sugar and loss sugar yields in the first and the second seasons, respectively.

Nitrogen fertilization exerted significant effect on NUE for roots, gross sugar, white sugar and loss sugar yields in both seasons. The values of NUE for gross sugar yield (in the second season, only), and white sugar yield (in the both seasons) gradually increased by increasing nitrogen from 80 to $120 \mathrm{Kg} \mathrm{N} / \mathrm{fed}$. On contrary, increasing nitrogen rate from 80 to $120 \mathrm{Kg}$ $\mathrm{N} /$ fed. significantly decreased values of NUE for roots yield (in the first season only) and loss sugar yield (in the two seasons). On the other hand, the highest values of NUE for gross sugar yield $(48.82 \mathrm{Kg} / \mathrm{Kg} \mathrm{N})$ in the first season and NUE for roots yield $(240.3 \mathrm{Kg} / \mathrm{Kg} \mathrm{N})$ in the second season were recorded with application nitrogen fertilizer at the rate of $100 \mathrm{Kg} \mathrm{N} /$ fed.

Regarding the interaction between nitrogen sources and its rates was significant for NUE for roots yield, gross sugar yield and white sugar yield in the two seasons and for loss sugar yield in the second season only. Generally, application of ammonium sulphate with $120 \mathrm{Kg} \mathrm{N} /$ fed. gave the highest values of NUE for gross sugar and white sugar yields in both seasons. While, application the same fertilizer at the rate of 80 $\mathrm{Kg} \mathrm{N} /$ fed. recoded the greatest values of NUE for roots yield (in the first season) and loss sugar yield (in the two seasons). The highest NUE value for roots yield in the second season obtained with application ammonium sulphate at the rate of $100 \mathrm{Kg} \mathrm{N} / \mathrm{fed}$. In this regards, Terry, (2008) and Jon et al., (2009) suggested that higher NUE reduced applied fertilizer and less nitrogen application cost.

Table 6. Effect of two sources and three rates of nitrogen fertilizer on sugarbeet impurity parameters during 2018/ 19 and 2019/ 20 seasons

\begin{tabular}{|c|c|c|c|c|c|c|c|c|c|}
\hline \multirow{2}{*}{ Treatments } & \multirow{2}{*}{ N Rates } & \multicolumn{4}{|c|}{$2018 / 19$} & \multicolumn{4}{|c|}{$2019 / 20$} \\
\hline & & $\mathbf{K} \%$ & $\mathrm{N \%}$ & $\alpha-\mathbf{N}$ & $\mathbf{A C}$ & $\mathrm{K} \%$ & $\mathbf{N \%}$ & $\alpha-\mathbf{N}$ & $\mathbf{A C}$ \\
\hline \multirow{3}{*}{ Urea $46 \%$} & 80 & 5.41 & 2.89 & 3.45 & 2.40 & 5.08 & 3.18 & 3.42 & 2.42 \\
\hline & 100 & 5.39 & 2.86 & 2.92 & 2.84 & 4.72 & 2.55 & 3.01 & 2.43 \\
\hline & 120 & 4.84 & 2.71 & 2.89 & 2.63 & 4.31 & 2.50 & 2.95 & 2.36 \\
\hline \multirow{3}{*}{$\begin{array}{c}\text { Ammonium } \\
\text { sulphate } \\
20.6 \%\end{array}$} & 80 & 5.72 & 2.78 & 2.94 & 2.91 & 5.14 & 2.68 & 3.39 & 2.31 \\
\hline & 100 & 4.80 & 2.45 & 2.66 & 2.73 & 4.64 & 2.55 & 2.53 & 2.85 \\
\hline & 120 & 3.48 & 2.16 & 2.40 & 2.36 & 4.01 & 2.30 & 2.53 & 2.51 \\
\hline \multicolumn{2}{|c|}{ LSD $_{0.05}$} & 0.08 & 0.21 & 0.11 & 0.18 & 0.18 & $\mathbf{0 . 1 7}$ & 0.25 & 0.14 \\
\hline \multirow{3}{*}{ N/Fed } & 80 & 5.57 & 2.84 & 3.20 & 2.65 & 5.11 & 2.93 & 3.41 & 2.37 \\
\hline & 100 & 5.10 & 2.66 & 2.79 & 2.78 & 4.68 & 2.55 & 2.77 & 2.64 \\
\hline & 120 & 4.16 & 2.44 & 2.65 & 2.50 & 4.16 & 2.40 & 2.74 & 2.43 \\
\hline \multicolumn{2}{|c|}{ LSD $_{0.05}$} & 0.06 & 0.15 & 0.08 & 0.13 & 0.13 & 0.12 & 0.18 & 0.10 \\
\hline \multirow{2}{*}{ Sources } & $\begin{array}{c}\text { Urea } 46 \% \\
\text { Ammonium }\end{array}$ & 5.21 & 2.82 & 3.09 & 2.62 & 4.70 & 2.74 & 3.13 & 2.40 \\
\hline & $\begin{array}{c}\text { sulphate } \\
20.6 \%\end{array}$ & 4.67 & 2.46 & 2.67 & 2.67 & 4.60 & 2.51 & 2.82 & 2.56 \\
\hline \multicolumn{2}{|c|}{ LSD $_{0.05}$} & 0.28 & ns & 0.10 & Ns & ns & 0.22 & 0.23 & ns \\
\hline
\end{tabular}


Table 7. Effect of two sources and three rates of nitrogen fertilizer on nitrogen use efficiency (NUE) for sugarbeet yields $(\mathrm{Kg} / \mathrm{Kg} \mathrm{N})$ during 2018/19 and 2019/ 20 seasons

\begin{tabular}{|c|c|c|c|c|c|c|c|c|c|}
\hline \multirow[b]{2}{*}{ Treatments } & \multirow[b]{2}{*}{ N Rates } & \multicolumn{4}{|c|}{ 2018/19 } & \multicolumn{4}{|c|}{$2019 / 20$} \\
\hline & & $\begin{array}{l}\text { Roots } \\
\text { yield }\end{array}$ & $\begin{array}{c}\text { Gross } \\
\text { Sugar } \\
\text { yield }\end{array}$ & $\begin{array}{l}\text { White } \\
\text { sugar } \\
\text { yield }\end{array}$ & $\begin{array}{c}\text { Loss } \\
\text { sugar } \\
\text { yield }\end{array}$ & $\begin{array}{l}\text { Roots } \\
\text { yield }\end{array}$ & $\begin{array}{c}\text { Gross } \\
\text { Sugar } \\
\text { yield }\end{array}$ & $\begin{array}{c}\text { White } \\
\text { sugar } \\
\text { yield }\end{array}$ & $\begin{array}{r}\text { Loss } \\
\text { sugar } \\
\text { yield } \\
\end{array}$ \\
\hline \multirow{3}{*}{ Urea $46 \%$} & 80 & 247.50 & 43.05 & 34.50 & 8.55 & 214.50 & 38.16 & 32.28 & 5.88 \\
\hline & 100 & 251.50 & 44.62 & 36.08 & 8.54 & 211.90 & 38.65 & 33.54 & 5.11 \\
\hline & 120 & 229.25 & 42.31 & 35.10 & 7.21 & 216.42 & 40.64 & 35.76 & 4.87 \\
\hline \multirow{3}{*}{$\begin{array}{c}\text { Ammonium } \\
\text { sulphate } \\
20.6 \%\end{array}$} & 80 & 293.13 & 51.59 & 41.37 & 10.21 & 247.88 & 42.99 & 36.55 & 6.44 \\
\hline & 100 & 283.10 & 53.03 & 44.44 & 8.59 & 268.70 & 49.14 & 42.74 & 6.40 \\
\hline & 120 & 262.50 & 53.16 & 46.69 & 6.46 & 255.00 & 50.49 & 45.17 & 5.32 \\
\hline \multicolumn{2}{|c|}{$\mathbf{L S D}_{0.05}$} & 3.15 & 4.66 & 1.00 & ns & 6.48 & 2.05 & 2.04 & 0.37 \\
\hline \multirow{3}{*}{ N/Fed } & 80 & 270.31 & 47.32 & 37.94 & 9.38 & 231.19 & 40.58 & 34.41 & 6.16 \\
\hline & 100 & 267.30 & 48.82 & 40.26 & 8.56 & 240.30 & 43.90 & 38.14 & 5.76 \\
\hline & 120 & 245.88 & 47.73 & 40.90 & 6.84 & 235.71 & 45.56 & 40.47 & 5.09 \\
\hline \multicolumn{2}{|c|}{ LSD $_{0.05}$} & 2.22 & 0.29 & 0.71 & 1.80 & 4.58 & 1.45 & 1.44 & 0.26 \\
\hline \multirow[b]{2}{*}{ Sources } & Urea $46 \%$ & 242.75 & 43.33 & 35.23 & 8.10 & 214.27 & 39.15 & 33.86 & 5.29 \\
\hline & $\begin{array}{c}\text { Ammonium } \\
\text { sulphate } \\
20.6 \%\end{array}$ & 279.58 & 52.59 & 44.17 & 8.42 & 257.19 & 47.54 & 41.49 & 6.05 \\
\hline \multicolumn{2}{|c|}{ LSD $_{0.05}$} & 2.05 & 3.35 & 1.37 & 0.14 & 14.39 & 3.29 & 2.37 & ns \\
\hline
\end{tabular}

It could be recommended to apply ammonium sulphate fertilizer at a rate of $120 \mathrm{Kg} \mathrm{N} /$ fed Bangar ElSukar region, because it increases the yield components, quality percentages and photosynthetic pigments as well as NUE for gross sugar and white sugar yields, and reduces loss sugar yield, loss sugar percent, and all impurities concentrations.

\section{REFERENCE}

A.O.A.C. 1995. Association Official Analytical Chemists, official methods analysis, $16^{\text {th }}$ edition; the international Washington, DC. Cook, D.A. and R.K.

Abd El- Kader, E. M. A. 2011. Effect of nitrogen fertilizer and some growth regulators treatments on sugarbeet. J. Plant Production, Mansoura Univ., 2 (12): 1693 - 1702, 2011.

Abdelaal, Kh. A. A. and S. F. Tawfik. 2015. Response of Sugarbeet Plant (Beta vulgaris L.) to mineral nitrogen fertilization and bio- fertilizers. Current Microbi. and Appl. Sci. ,4 (9) : 677- 688.

Abdou, M. A. 2013. Effect of nitrogen fertilization and harvesting dates on sugarbeet productivity and quality in newly reclaimed sandy soils. J. Plant Production, Mansoura Univ., 4 (12): 1871 - 1882

Abdou, M. A., D. I. H. El- Geddawy and A. M. Elwan. 2014. Productivity and quality of sugarbeet as affected by plant distribution pattern and nitrogen fertilizer level. J. Plant Produ., Mansoura Univ., 5 (12): 2057- 2068.

Abdou, M. A. E. 2014. Response of sugarbeet (Beta vulgaris L) productivity to potassium fertilization. Zagazig. J. Agric. Res., 41(5): 961- 968.
Abo El-Ghait, R.A. and S.G.A. Mohamed. 2005. Agronomical and statistical studies on the response of some sugar beet varieties to nitrogen application. Minufiya J. Agric. Res.. 30(6).1805-1821.

Abou- Shady, Kh. A., E. H. Omar and H. H. El- Sebaay. 2008. Influence of sulphur, biofertilizer and mineral nitrogen on sugarbeet yield components, technological characters and soil elemental content. J. Agric. Res., Kafr ElSheikh Univ. 34(1): 309-330.

Agami, K. M. 2005. Effect of planting date, plowing depth and nitrogen fertilizer on yield and quality of sugarbeet at Noubaria. Ph.D. Thesis, Fac. Agric., Moshtohor, Zagazig Univ.

Allam, A. Y. 2003. Response of three wheat cultivars to split application of nitrogen fertilization rates in sandy soil. Assiut J. Agric. Sci., 34 (1): 1- 14.

Allam, S. M. 2009 . Quality, lectnological and productivity aspects of sugarbeet as influence by nitrogen, potassium and boron fertilizers. Egypt. J. Appl. Sci. 23 (1): 141155.

Attia, K. and Y. A. M. M. Khalifa. 2015.Response of sugarbeet grown in newly reclaimed soil to different nitrogen sources at different growth stages. Middle East J. of Agric. Res., 4: 467- 474.

Black, C. A., D. D., Evans, L. E., Ensminger, G. L. White and F. E. Clark. 1981. Methods of soil analysis. Part 2 pp. 1100. Agron. Inc. Madison. W. I., USA.

Cook and Scott. 1993. The Sugar Beet Crop. Sciens Practic published by Chapman and Hall, London.

El- Geddawy, D. I. H. and B. S. I. Makhlouf. 2015. Effect of hill spacing and nitrogen and boron fertilization levels on yield and quality attributes in sugarbeet. Menufiya J. Agric. Res. 40(4): 959-980. 
El- Sarag, E.I. 2008. Maximizing sugar beet yield, quality and water use efficiency using some agricultural practices under North Sinai conditions. Bull. Fac., Agric., Cairo Univ., 60: 155-167.

El- Sayed, S. S. M. 2013. Yield and quality of sugarbeet as affecting by zinc foliar application under different nitrogen fertilization levels. J. Plant Production, Mansoura Univ., 4 (2): 351 - 362.

El- Sheref, A. E. M. 2007. Studien yields and quality of sugarbeet crop. M. Sci. Thesis Fac. Agric. Tanta Univ., Egypy.

El- Sonbaty, M. M., G. H. Abdel - Hay, E. A.E. Nemeat-Alla and E. A. El-Tahawey. 2012.Effect of source, rate and application time of nitrogen fertilizer on sugar beet. J. Plant Production, Mansoura Univ.3 (11): 2903 - 2912

Elkady, M. S. M. 2015. Study of water and fertilization stresses on yield and quality of sugarbeet under two modern irrigation systems in sandy soils. Ph D Thesis, Cairo Univ. Fac.of Agric.:129 p.

Faust, S. Schubert. 2016.Protein synthesis is the most sensitive process when potassium is substituted by sodium in the nutrition of sugarbeet (Beta vulgaris L.). Plant Physiol. Biochem., 107: 237- 247.

Fei, C., H. Fan and G. Xu. 2020. Estimation of total nitrogen content in sugarbeet on chlorophyll fluorescence parameters. Photosynthetica, 58 (3): 869-872.

Gharib, H. S. and A. S. EL- Henawy. 2011.Response of sugarbeet (Beta vulgaris, $L$ ) to irrigation regime, nitrogen rate and micronutrients application.Alex. Scie. Exch..32(2): 140-156.

Gomaa, M. A., G. Abdel- Nasser,M. F. Maareg and M. M. ElKholi. 2017. Sugarbeet response to nitrogen and potassium fertilization treatments in sandy soil. J. Adv. Agric. Res. Fac. Agric. (Saba Basha), Univ. Alexandria 22(2): 272-287.

Grodzinsky, A. M. and D. M. Grodzinsky. 1973.Short reference in plant physiology. Naukova Domka, Riev. R. U. R. :933- 934.

Groves, S. J. and R. J. Bailey. 1994.Strategies for the suboptimal irrigation of sugarbeet. Efficiency of water use in crop systems, Reading, UK, 6- 8 July 1994. Aspects of Applied Biology, 38: 201-

Hozayn, M., A. M. Korayem, A. M. El- Saady, M. A. Darwish, A. A. Abd El- Monem and E. M. Abd ElLateef. 2014. Sugarbeet productivity as influenced by sources and over doses of nitrogen fertilizers grown in cly soil. Middel East J. Agri. Res., 3 (4): 1189- 1195.

Ibrahim, M. M., Kh. A. O. El- Aref and A. S. Abo El- Hamd. 2005. Effect of nitrogen and phosphorus fertilization on yield and quality of two Sugarbeet varieties under Assuit Governorate condition Zagazig J. Agric. Res. 32(4): 1087-1103.

Ismail, A. M. and R. A. Abo El- Ghait. 2005. Effect of nitrogen sources and rates on yield and quality of sugarbeet. Egypt. J. Agric. Res., 83 (1): 229-240.

Jackson, M. I. 1973. Soil chemical analysis. Prentice Hall Inc. Englewood cliffs, N. J., USA.

Jon, T., F. M. Biermacher, B. Epplin, B. Wade, B. John, S. William and R. Raun. 2009. Economic feasibility of sitespecific optical sensing for managing nitrogen fertilizer for growing wheat. Precision Agric., 10: 213-230.
Kandil, A. A., S. A. El- Morsy, A. M. Salama and H. M. Sarahan. 2016. Improvement sugarbeet productivity in newly reclaimed sandy saline soils by using soil amendments and nitrogen fertilizer splitting levels. STC Agriculture and Natural Resources 2 (1): 01-18.

Khedr, A. H. and E. A. E. Nemeat- Alla. 2006. Response of barley to intercropping with sugarbeet under different nitrogen fertilization levels. J. Agric. Sci. Mansoura.31:4957-4968.

Maareg, M. F., K. M. Agami and A. M. Ebeid. 2020. Effect of sources and rates of nitrogen fertilizer on reproduction of root- knot nematode, Meloidogyine incognita and productivity of sugar beet. Egyp. J. Agronematol., under publication.

Maareg, M. F., S. F.Twafik and A. A. Abo El Ftooh. 2005a. Effect of preceding crops and nitrogen fertilization on productivity of sugarbeet and some economic insect pests infestation in Newly Reclaimed Soil at West Nubaryia Region The Third International Conference on IPM Role in Integrated Crop management and Impacts on Environment and Agri. Products. 26-29 November Giza, Egypt. (published in Egypt. J. Agric. Res. ,83 (2): 741757).

Maareg, M. F., S. F.Twafik and I. M. A. Gohar. 2005 b. Effect of split and amount application of nitrogen fertilizer to sugarbeet on root- knot nematode, Meloidogyne javanica and crop production under sprinkler irrigation in sandy soil . The Third International Conference on IPM Role in Integrated Crop management and Impacts on Environment and Agri. Products. 26-29 November Giza, Egypt. (published in Egypt. J. Agric. Res. 83 (2): 687706).

Mekdad, A. A. A. 2015. Sugarbeet productivity as affected by nitrogen fertilizer and foliar spraying with boron. International $\mathrm{J}$. of Current MicroBio. and Applied Sciences 4(4): 181- 196.

Mengutary, M. Ceylan, U.B. Kutman and I. Cakmak. 2013. Adequante magnesium nutrition mitigates adverse effects of heat stress on maize and wheat. Plant and Soil, 368:5772.

Moustafa, Ze. R., A. M. K. Soudi and K. M. El- Shenawy. 2011. Productivity and quality of sugarbeet as influenced by nitrogen fertilizer and some micronutrients Egypt. J. Agric. Res., 89 (3):2105-1018.

Naresh, R. K. 2020.Research trends in Agriculture Science. Ed. By Aklnik Publications New Delhi, 243 pp.

Nemeat- Alla, H. E. A. E. 2009. Effect of nitrogen, calcium and boron fertilization on productivity and quality of sugarbeet under different planting pattern. Ph.D. Thesis, Kafr El-Sheikh University. Fac. of Agriculture. Agronomy Department, $130 \mathrm{p}$.

Osman, A. M. H. 2011. Influence of foliar spray of some micronutrients and nitrogen on productivity of sugarbeet under newly reclaimed soils. J. Plant Production, Mansoura Univ., 2 (9): 1113 - 1122.

Osman, M. S., A. M. Okaz, M. A. Soliman, H. A. Hosny and M. F. El-_Enany. 2010. Response of sugarbeet to nitrogen fertilizer and sulphar spray frequency in Middle Egypt. Egypt. J. Agric. Res. 83 (3): 1237-1254. 
Sarhan, H. M. 2012. Effect of bio- and mineral fertilization on yield and quality of sugarbeet. J. of Plant Production, Mansoura University, 11(3): 2513-2524.

Sarhan, H. M., M. A. E. Abdou and H. M. Al- Sayed. 2012. Effect of planting systems and plantdensity and nitrogen fertilizer levels on productivity and quality of sugarbeet. J. Plant Production, Mansoura Univ., 3 (10): 2567 2580 .

Shaban, KH. A. H., E. M. Abdel Fatah and D.A. Syed. 2014. Impact of humic acid and mineral nitrogen fertilization on soil chemical properties and yield and quality of sugarbeet under saline soil. J. Soil Sci. and Agric. Eng., Mansoura Univ., 5 (10): 1335 - 1353.

Soliman, E. M., M. A. El - Hawary, I. M. Abdel- Aziz, O. A. O. Mazen and S. A. Mohamed.2013. Effect of irrigation water quality, sources and rates of nitrogen on growth and quality of sugarbeet. J. Plant Production, Mansoura Univ., 4 (4): 537 - 550.

Sugar Crops Council. 2020. Annual report "Sugar crops and sugar production in Egypt in 2018/2019 growing and Juice 2020 season"
Terry, L. R. 2008. Improving nutrient use efficiency. Turk. J. Agric. For., 32:177-182.

Trankner, M., B. Jakli, E. Tanakol, G. J. Cakmak, K. Dittert and M. Senbayran. 2016. Magnesium deficiency decreases biomass water use efficiency and oxidative stress in barley plants. Plant and Soil, 406: 409- 423.

Watson, D. J. 1958. The dependence of net assimilation rate on leaf area index. Ann. Bot. Lond. N. S., 22: 37- 54.

Wettestien, D. V. 1957. Chlorophyll, lethal und submikroskopische formel wechsel der plastiden Exptl. Cell Res., 12: 427- 433.

Wu, Y. W., Q. Li, R. Jin. 2019. Effect of low nitrogen stress on photosynthesis and chlorophyll fluorescence characteristics of maize cultivars with different lownitrogen tolerances. J. Lenlegr. Agric., 18: 1246- 1256. 




أثر إستخدام التسميد النيتروجيني من مصادر ومعدلات مختلفة على نمو ومكونات المحصول

\section{والجودة وكفاءة التسميد النيتروجيني لبنجر السكر مئر}

حسام محمد الثرنوبي

- ومن جهة آخرى أظهر التسميد بكبريتات الأمونيوم إنخفاضا معنويا في كل من : البوتاسيوم K والصوديوم Na

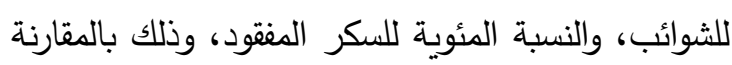
بالتسميد باليوريا في كلا الموسمين. - كما أعطت معدلات التسميد النيتروجني المختلفة تأثيرا

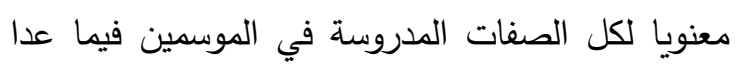

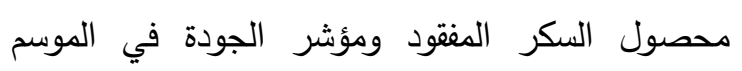

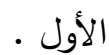

- التسميد بمعدل • ب ا كجم نيتروجين للفدان سجل أعلى قيم لكل من حجم الجذور ومعظم مكونات المحصول وصفات الجودة و NUE لمحصول لمدئ السكر الكلي ومحصول السكر الأبيض. كما سجل هذا المعدل التسميد أقل قيم للشوائب (K, Na, $\alpha$-amino N, AC)

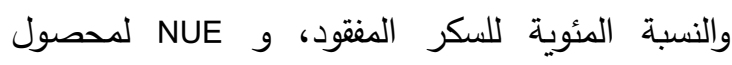
الجذور ومحصول السكر المفقود في كلا الموسمين. - التفاعل بين مصادر ومعدلات التسميد النيتروجيني اثرت

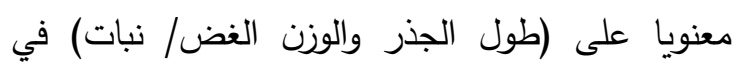

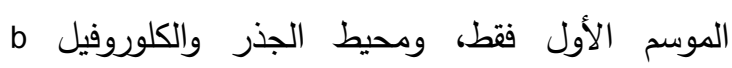

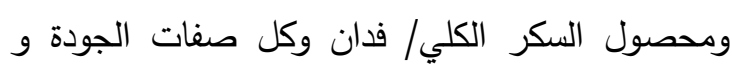
لمحصول السكر الدفقود في الموسم الثاني فقط. - كما أظهر التفاعل بين مصادر ومعدلات التسميد

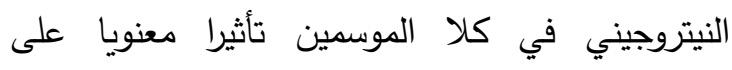

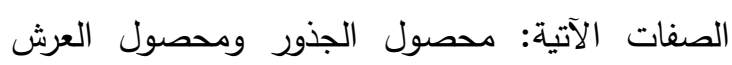

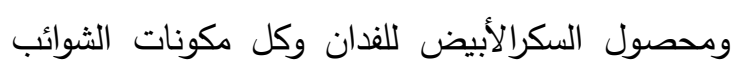

- نفذت تجربتان حقليتان بمنطقة بنجر السكر بمدينة برج

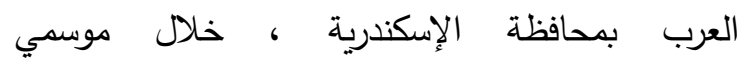

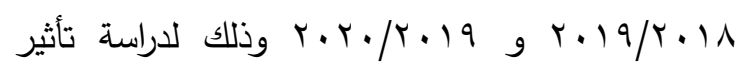
التسميد بصدرين مختلفين من النيتروجين (سلفات

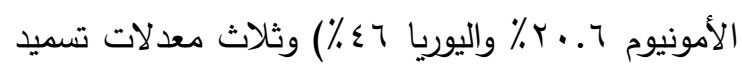

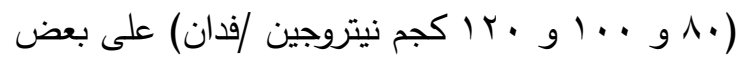
صفات النمو والمحصول وخصائص الجودة وكذلك

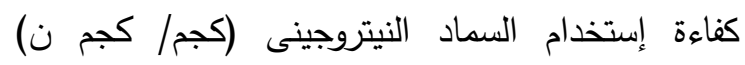
لمحصول بنجر السكر وتم إستخدام تصميم القطع المنشقه مره واحده فى أربع مكررات. - أظهرت النتائج وجود إختلافات معنوية سجلت بين مصادر ملحرد التسميد النيتروجيني المستخدم في معظم صفات النمو ومكونات المصول وخصائص الجودة والشوائب وكذلك في الكئ كفاءة استخدام النيتروجين (NUE) في الموسمين. - نباتات بنجر السكر التي تم تسميدها بكبريتات الأمونيوم

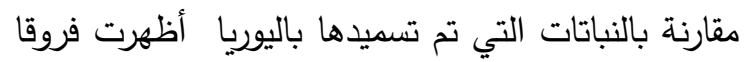

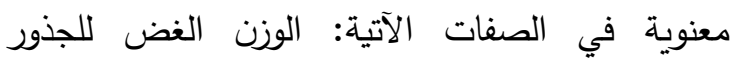

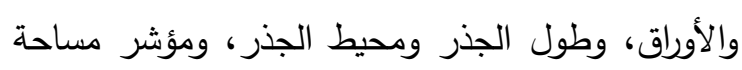
الورقة (LAI)، وتراكم المادة الجافة للنبات كمؤشر

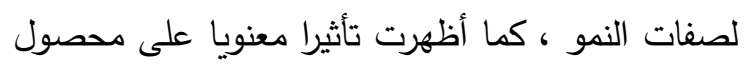
الجذور ومحصول العرش ومحصول السكر الكلي

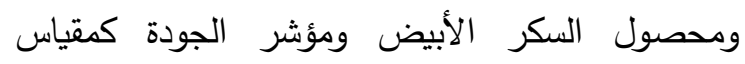

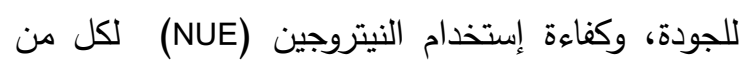
محصول الجذور والسكر الكلي والسكر الأبيض والسكر المفقود في كلا الموسمين، والكلوروفيل a في الموسم الإلمر الأول فقط. 
NUE السكر المفقود ولمحصول السكر المفقود و و لمحصول الجذور وكل مكونات الثوائب.

- الذا فانه ينصح باستخدام كبريتات الأمونيوم بمعدل . كجم نتروجين للفدان فى منطقة بنجر السكر ببرج العرب بمحافظة الإسكندرية.
بالإضافة إلى NUE لمحصول الجذور ومحصول السكر الكلي ومحصول السكر الأبيض. - وفي العموم أظهر التسميد بكبريتات الأمونيوم بمعدل . IT كجم/فدان أعلى قيم لحجم الجذور والكلوروفيل b ومعظم صفات المحصول وصفات الجودة و NUE للسكر الكلي ومحصول السكر الأبيض، كما أعطى أقل قيم لنسبة 